\title{
Treatment of wastewater from the dairy industry with Moringa Oleifera using two
}

\section{different methods}

\author{
Tratamento de águas residuais da indústria de laticínios com Moringa Oleífera usando dois \\ métodos diferentes
}

Tratamiento de aguas residuales de la industria láctea con Moringa Oleífera mediante dos métodos diferentes

\begin{abstract}
Dairy foods represent a large market, grossing more than $\$ 125$ billion per year worldwide. Dairy effluent has high organic load and therefore must be treated before disposing in the water bodies. Natural coagulants represent a good option for effluent treatment, among which is the Moringa Oleífera (MO) seed. In this sense, the present work experimentally evaluates the effluent treatment efficiency of the dairy industrial effluents using coagulants based on the MO seed, also discussing environmental and economic potentialities of seed planting. Evaluation was carried out by use of the MO seed both directly (comminuted) and in saline solution by Jar Test essay. The COD clarification and removal efficiency of the crude sample was evaluated for different initial turbidity and coagulant volume scenarios. The results showed a high turbidity reduction efficiency (between 97 and 99\%) in most of the tests by the direct use of MO seeds. The cropped area required for this application in a dairy industry with processing of $10 \mathrm{~m}^{3}$ of milk per day was $1775 \mathrm{~m}^{2}$. The use of MO seed in saline solution did not achieve the same efficiency, indicating the need to optimize the test parameters. The results might to base more extensive discussions of potentialities and limitations of the use of MO seed as a potential coagulant.
\end{abstract}

Keywords: Clarification; Moringa Oleífera; Dairy effluent; COD removal.

\section{Resumo}

A indústria de laticínio é extremamente importante para a economica Brasileira, sendo que o país possui mais de 2 mil laticinios e movimenta cerca de 19 bilhoes de USD/ano neste setor. O efluente gerado pela industria de laticinios tem alto carga orgânica e, portanto, deve ser tratado antes de ser disposto nos corpos hidricos. Uma das opções para tratamento de efluentes é o uso de coagulantes naturais, como a semente da Moringa Oleífera (MO). Neste contexto, o presente trabalho avalia experimentalmente a eficiência de tratamento de efluentes da industria de laticinio utilizando coagulantes a base da semente de MO, discutindo as potencialidades ambientais e econômicas do plantio de MO para esta aplicação. Avaliação foi realizada considerando o uso da semente de MO tanto de forma direta (triturada) como também em solução salina por meio do ensaio Jar Test. A eficiência de clarificação e remoção de DQO da amostra bruta foram avaliadas para diversos cenários de turbidez inicial e volume de coagulante. Os resultados obtidos demonstraram que o uso direto da farinha de semente de MO apresentou elevada eficiência de redução de turbidez na 
maioria dos ensaios, sendo obtidos resultados entre 97 e 99\%. A área d eplantio necessário para esta aplicação em um laticinio com processamento de $10 \mathrm{~m}^{3}$ de leite por dia foi de $1775 \mathrm{~m}^{2}$. O uso da $\mathrm{MO}$ em solução salina não obteve a mesma eficiência, indicando a necessidade de otimização dos parâmetros de ensaio. Discussões mais amplas das potencialidades e limitações do uso da MO puderam ser construídas a partir dos resultados obtidos.

Palavras-chave: Clarificação; Moringa Oleífera; Efluentes de laticínios; Remoção de DQO.

\section{Resumen}

La industria láctea es extremadamente importante para la economía brasileña, ya que el país tiene más de 2.000 productos lácteos y maneja alrededor de 19 mil millones de dólares anuales en este sector. El efluente generado por la industria láctea tiene una alta carga orgánica y por lo tanto debe ser tratado antes de ser depositado en cuerpos de agua. Una de las opciones para el tratamiento de efluentes es el uso de coagulantes naturales, como la semilla de Moringa Oleífera (MO). En este contexto, el presente trabajo evalúa experimentalmente la eficiencia del tratamiento de efluentes de la industria láctea utilizando coagulantes basados en la semilla de MO, discutiendo el potencial ambiental y económico de la siembra de MO para esta aplicación. La evaluación se realizó considerando el uso de semilla de MO tanto directamente (triturada) como también en solución salina a través del Jar Test. Se evaluó la eficiencia de clarificación y eliminación de DQO de la muestra cruda para varios escenarios de turbidez inicial y volumen de coagulante. Los resultados obtenidos demostraron que el uso directo de la harina de semilla de MO mostró una alta eficiencia en la reducción de la turbidez en la mayoría de las pruebas, con resultados entre 97 y $99 \%$. El área de siembra requerida para esta aplicación en una lechería que procesa $10 \mathrm{~m}^{3}$ de leche por día fue de $1775 \mathrm{~m}^{2}$. El uso de MO en solución salina no logró la misma eficiencia, lo que indica la necesidad de optimizar los parámetros de prueba. Se podrían construir discusiones más amplias sobre los potenciales y limitaciones del uso de MO en base a los resultados obtenidos.

Palabras clave: Clarificación; Moringa Oleífera; Efluentes lácteos; Remoción de DQO.

\section{Introduction}

Dairy foods represent a large market, grossing more than $\$ 125$ billion per year worldwide (Mccain et al., 2018). Dairy consumption tends to increase in coming years because it provides essential nutrients more efficiently than many other agricultural systems (Britt et al., 2018). In Brazil, the dairy industry is very important, due to the large number of existing dairy establishments (medium and small sized), such industry is characterized by expressive generated jobs and the value aggregation and income generation for the parents (Lima et al., 2017). According to Formigoni (2017), Brazilian milk production was 34 billion liters in 2016, generating a turnover of 19.3 billion USD in this year, making Brazil the fourth largest producer in the world ranking, with approximately 23 million dairy cows, 1.3 million dairy farmers and 2,000 dairy farms with inspection.

The large water amount to produce dairy products places the dairy industry as a major effluent source. Five liters of effluents are generated to treat two liters of milk, which, when discharged with pollutants in waterbodies, generates a quality modification and consequently, its pollution (Begnini and Ribeiro, 2014). Dairy effluents are mainly composed of proteins, such as casein, carbohydrates, mainly lactose, fats, suspended solids, nitrogen, phosphorus and also inorganic pollutants (Britz et al., 2008). Its high values of biochemical oxygen demand (BOD) and chemical oxygen demand (COD) as a consequence of the large amount of lipids, carbohydrates and proteins, which give the system a high organic load. If released into waterbodies without proper treatment, it drastically reduces the concentration of dissolved oxygen and endanger the entire water ecosystem (Villa et al., 2007).

The pollutants concentrations ranges in dairy effluent are quite broad as these values can vary greatly according to each product, the time of year and the water and effluent management practices applied in each industry (Andrade, 2011).

In order to alleviate industrial effluents treatment problems, several techniques have been studied, among them the use of natural coagulants. When produced locally and with a low financial cost, can provide attenuation in the consumption of nonpotable water and wastewater discharges, without treatment, in receiving waterbodies. Natural coagulants / flocculants have shown advantages over chemicals, especially in relation to biodegradability, low toxicity and low production of residual sludge (Lo Monaco et al., 2010). 
Among the best-known natural coagulants, the Moringa oleifera (MO) seed stands out. The tree belongs to the family Moringaceae, native to India. It is a tree with multiple potential applications (Bancessi et al., 2019) and was introduced in Northeast region of Brazil around 1950, mainly in the States of Maranhão, Piauí and Ceará (Pozzobon e Kempka, 2015). The seed can be used as a coagulant directly by the flour of after grinding and sieving (primary process); the same flour may be mixed with water or salts for the production of coagulant solutions (secondary process); or subjected to more complex coagulant extraction techniques (such as dialysis, centrifugation, ion exchange, among others - tertiary process) (VillaseñorBasulto et al., 2018).

MO has rapid growth, about $1 \mathrm{~cm}$ per day (Junho, 2018), besides having a high seed yield and low production cost. Such seeds are much more advantageous in comparison to chemical coagulants due to its lower need to adjust $\mathrm{pH}$ at the end of treatment, low sludge volume production and low operating cost. According to Rangel (2018), MO requires little crop care and grows rapidly to a height of $4 \mathrm{~m}$ in the first year, and when conditions are favorable, a single plant can produce 50 to $70 \mathrm{~kg}$ of fruit per year.

To Paterniani (2009), MO seeds contain low molecular weight proteins; as its powder is dissolved in water it acquires positive charges, which attract negatively charged particles such as clays and silt, forming dense, sediment flakes. Studies have not detected human health risks if MO seeds are used at low doses in the process of clarification and reduction of water turbidity, with no toxicity in their use. (Valverde et al., 2013). in addition to coagulant production, MO seeds also might have various purposes: human food for nutritional supplementation, agriculture as animal feed, such as grange breed proposed by Macambira et al. (2018), biodiesel production as a source of income for the producer (application studied by Silva et al., 2010 and Fernandes et al., 2019), among others. A complete review of MO different parts applications can be obtained in Liu et al. (2018).

Several authors have evaluated the efficiency of using MO for various types of effluents under the most varied methodologies. Rocha et al. (2018) evaluated the efficiency of turbidity and color removal from high turbidity surface waters by Jar Test, obtaining results above $90 \%$ in the vast majority of the scenarios analyzed. Adesina et al. (2019) optimized the coagulation parameters for the treatment of surface water. Optimum condition established was, agitation time of $10 \mathrm{~min}$, agitation speed of $100 \mathrm{rpm}$, settling time of $120 \mathrm{~min}$ and $3 \mathrm{~g} / \mathrm{l}$ of MO concentration. Garde et al. (2017) evaluated the treatment of fermentation water in coffee processing. The authors used an MO Solution in distilled water and evaluated the effluent clarification, detecting that the MO is inactive for $\mathrm{pH}$ ranges 3 and 4 in the effluent treatment. Authors such as Carnacho et al. (2016) and Moreno et al. (2016) has evaluated the application of MO to remove algae and or cyanobacteria, which shows the scope of this coagulant.

Some authors have also studied the MO seed application in the treatment of dairy effluents, due to the importance of this industry to several countries. Vieira et al. (2009) verified the coagulation and flocculation efficiency at different agitation times, $\mathrm{pH}$, organic load and coagulant concentration, for a single turbidity and for an effluent synthesized from water and industrial milk powder. The authors obtained higher efficiency of color removal, turbidity and residual COD in the coagulation / flocculation test for a coagulant powder concentration of $\mathrm{MO}$ of $1 \mathrm{~g} / \mathrm{L}$ and $\mathrm{pH}$ between 5 and 8 . With these results, a removal around $99 \%$ for turbidity and $97 \%$ for color.

Formentini-Schmitt et al (2014), evaluated the MO efficiency for clarification in terms of apparent color removal, turbidity and chemical oxygen demand (COD) in different saline solutions $(1.0 \mathrm{M} \mathrm{KCl}$ and $1.0 \mathrm{M} \mathrm{NaCl})$ using an effluent from a dairy industry in western Paraná State, Brazil. The authors found an optimal concentration of $1500 \mathrm{ppm}$ of the coagulant solution extracted with $1.0 \mathrm{M} \mathrm{KCl}$; $98.3 \%$ apparent color, $97.1 \%$ turbidity and 58.9\% COD removal.

However, some authors have not obtained satisfactory results in the clarification of dairy effluents using MO. Pereira et al. (2015) evaluated the application of $3000 \mathrm{mg} / \mathrm{L}$ of MO obtaining results of apparent color removal and turbidity after the 
flotation process of $24.10 \%$ and $27.6 \%$, respectively. The authors also evaluated a MO concentration of $2000 \mathrm{mg} / \mathrm{L}$, obtaining $40.37 \%$ turbidity removal. This fact demonstrates the importance of the test parameters for the satisfactory results of the treatment of these effluents with MO.

Due to the importance of the dairy industry and the feasibility of using natural coagulants, the present work aims to analyze the efficiency of the treatment of dairy effluent through MO seeds. This article differs from the others by using various concentrations of natural coagulant (in saline solution and by direct use of flour) compared to various initial effluent turbidity and COD values (important consideration given that the initial effluent turbidity of this industry is quite variable - Junho, 2018) and also by analyzing the planting area and the technical feasibility of the actual application of MO for treatment in dairy industries in Brazil.

\section{Methodology}

The present study is an experimental research. According to Koche (2011), this type of research study the cause-andeffect relationship of a given phenomenon transmitted by the manipulation of the quantity and quality of variables, employing a quantitative research. An experimental research is based on performing laboratory tests. In our case, the experiments were conducted using a methodology called JarTest (following the same methodology applied by Rocha et al., 2019). The collection and sampling techniques of the before and after the test were discovered in laboratory research, being developed according the recommendations of the American Public Health Associations (APHA), in Standard Methods for the Examination of Water and Wastewater (APHA, 2012).

\subsection{Laboratory tests}

The tests were performed at the Sanitation Laboratory of the Federal University of Itajubá, Brazil. For its execution, a synthetic dairy effluent was used (as used by Vieira et al., 2009). The clarification process was conducted using the MO seeds either directly (primary process) or prepared with a saline solution (secondary process) by the Jar Test, which comprises the clarification steps (coagulation, flocculation and sedimentation) of the effluent by the addition of coagulants. The steps required to perform the experiments are described in Figure 1.

Figure 1: Test method flowchart.

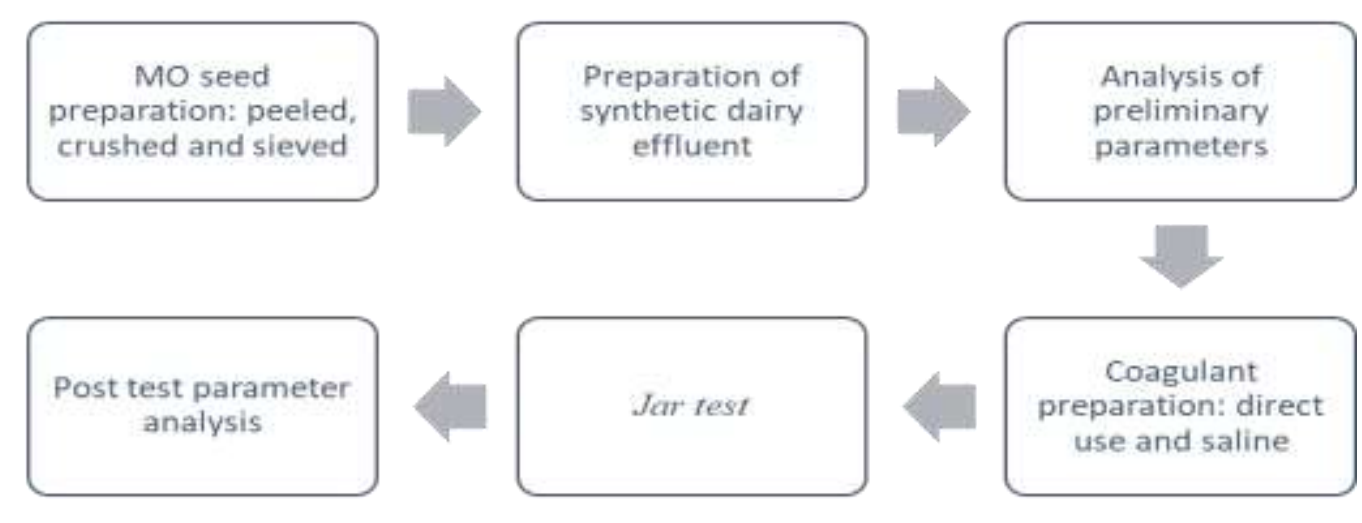

Source: Authors. 
The dairy effluent characteristics is very variable depending on the processes employed there, thus, it was estimated the mean and standard deviation of turbidity from several studies in the literature that worked with effluents from these industries (Andrade, 2011; Vieira et al., 2009; Machado, 2011 and Saraiva et al., 2009). The results obtained were equal to 900 \pm 450 NTU. Liquid whole milk was then mixed with water until the sample reached near desired turbidity values.

In order to analyze MO performance at different scenarios that comprised different turbidity values and different coagulant dosages, the following procedure was adopted to perform the tests: (i) Setting turbidity value at 900 NTU, and variation of coagulant volume; and (ii) Turbidity variation between 450, 900 and 1350 NTU (values previously calculated from mean and standard deviation) and use of a single coagulant volume. The same procedure was applied for the direct use of coagulant as well as for its use in saline solution.

For MO seed in saline solution we used Nkurunziza et al. (2009) and Madrona et al. (2010) methods. The following steps were required: (i) Weighing $2 \mathrm{~g}$ of peeled Moringa oil seeds, ground after weighing with the aid of a hand pestle; (ii) Preparation of a $1 \mathrm{~mol} / \mathrm{L} \mathrm{NaCl}$ solution using $11.89 \mathrm{~g}$ in $200 \mathrm{~mL}$ distilled water; and (iii) Homogenization of the saline sample with the seed powder.

The MO seed coagulant volume values in saline were adopted to be equal to the volume of required commercial Aluminum Sulfate for effluent treatment, if calculated by the method provided by the Minas Gerais State Sanitation Company, Brazil (COPASA, 2018), where the coagulant dosages are obtained as a function of the gross sample turbidity. This method was the same employed by Rocha et al. (2018), which obtained satisfactory results for high turbidity water clarification. The results obtained for coagulant volume are shown in Table 1 for dairy effluent showing the two types of tests, with fixed coagulant volume $(12.6 \mathrm{~mL})$ and later with fixed turbidity (900 NTU).

Table 1: Coagulant volume calculated for each dairy effluent sample for assay using OM in saline.

\begin{tabular}{|c|c|c|}
\hline Test & Turbidity (NTU) & $\begin{array}{c}\text { Coagulant Volume } \\
(\mathbf{m L})^{\mathbf{a}}\end{array}$ \\
\hline 1 & 450 & 12.6 \\
\hline 2 & 900 & 12.6 \\
\hline 3 & 1350 & 12.6 \\
\hline 4 & 900 & 4.6 \\
\hline 5 & 900 & \\
\hline \multicolumn{2}{|l}{} \\
\hline $\begin{array}{l}\text { The resulting MO seed mass in each of the coagulant volumes used (4.1, 7.6 and } \\
\text { Source: Authors. }\end{array}$ \\
\hline
\end{tabular}

To prepare MO-based coagulant with direct use of flour, the Vieira et al (2009) method was followed. When the seed pods were peeled, it was crushed with a pestle. Subsequently, the ground seeds were sieved in a $42 \mathrm{~mm}$ sieve. As performed by the authors, the optimum dosage of OM seed was $1.0 \mathrm{~g} / \mathrm{L}$, and the other values ranged from $0.5 \mathrm{~g} / \mathrm{L}$ to $1.25 \mathrm{~g} / \mathrm{L}$, as shown in Table 2. Thus, the optimal dose can be tested under different conditions than those tested by the authors. 
Table 2: MO seeds concentration for the dairy effluent test.

\begin{tabular}{|c|c|c|}
\hline Test & Turbidity (NTU) & Dosage (g/L) \\
\hline 1 & 450 & 1 \\
\hline 2 & 900 & 1 \\
\hline 3 & 1,350 & 1 \\
\hline 4 & 900 & 0.5 \\
\hline 5 & 900 & 0.75 \\
\hline 6 & 900 & 1.25 \\
\hline
\end{tabular}

Source: Authors.

Jar Tests were performed in 6 jars for both types of coagulants. For this test, a rotation speed of $200 \mathrm{rpm}$ for 1 minute (rapid mixing) was adopted. After that, the rotation was reduced to $100 \mathrm{rpm}$ for 40 minutes (Vieira et al., 2009). Then, the paddles were turned off and kept at rest for the floc sedimentation process (for 40 minutes for the saline OM and 60 minutes for direct use). Subsequently, we evaluated turbidity, $\mathrm{pH}, \mathrm{COD}$ and solid sediment parameters of the treated samples. A summary of the method employed in the final physicochemical analyzes is presented in Table 3 (APHA, 2012).

Table 3: Method for physicochemical analysis described in the Standard Methods for the Examination of Water and Wastewater.

\begin{tabular}{|c|c|}
\hline Analysis & Method \\
\hline Conductivity & Sample's conductivity was carried out on the Conductivity Meter. \\
\hline $\mathrm{pH}$ & Sample's $\mathrm{pH}$ was measured on the $\mathrm{pH}$ meter. \\
\hline Turbidity & Sample turbidity was measured. On the Turbidimeter \\
\hline Sedimented Solids & $\begin{array}{l}1 \mathrm{~L} \text { of sample was added to the Imhoff cone, and reading was performed after } 1 \text { hour of } \\
\text { sedimentation. }\end{array}$ \\
\hline $\begin{array}{c}\text { Chemical Oxygen } \\
\text { Demand - COD }\end{array}$ & $\begin{array}{l}1.5 \mathrm{ml} \mathrm{K} \mathrm{Cl}_{2} \mathrm{O}_{7} ; 3.5 \mathrm{ml} \text { of } \mathrm{H}_{2} \mathrm{SO}_{4} \text { and } 2.5 \mathrm{ml} \text { of the sample. It was taken to the digester for } 2 \text { hours at } \\
150{ }^{\circ} \mathrm{C} \text { and then the final reading was performed on the spectrophotometer. }\end{array}$ \\
\hline
\end{tabular}

\section{Source: Authors.}

\subsection{MO Planting Study}

A study was also carried out to verify the required area for the MO tree planting to supply the treatment of dairy effluent. Firstly, we calculated the effluent generation (equation 1) through the mean water consumption rate per liter of milk for dairy products with daily milk reception up to $10,000 \mathrm{~L}$ and the average wastewater generation.

$$
L_{e f}=T_{m} \cdot R \cdot A \cdot C o
$$

Where Lef is the effluent generation generated in L/y, Tm is the average water consumption rate per liter of milk in the amount of $2.9 \mathrm{~L} / \mathrm{L}$ milk, $\mathrm{R}$ is the daily dairy reception volume of $10000 \mathrm{~L} / \mathrm{d}$ (Saraiva et al., 2009), A is the number of days in a year equal to 365 days and $\mathrm{Co}$ is the coefficient correction given in $\mathrm{L}$ of effluent per $\mathrm{L}$ of water, equal to 1.05 calculated from average values presented. by Saraiva et al. (2009).

The data in Table 4 refer to MO seed yield per tree and the number of trees that can be planted per hectare. Using this information, we estimated the MO planting required area to supply the effluent treatment generated in the dairy by MO 
consumption per $\mathrm{L}$ obtained in the test with the best effluent treatment results and the total effluent generation.

Table 4: Parameters for estimative of MO mass and planting area required for coagulant production.

\begin{tabular}{|l|c|c|}
\hline \multicolumn{1}{|c|}{ Parameter } & Value & Refererence \\
\hline MO seed productivity per tree in kg/yr ${ }^{a}$ & 24 & Moringa Brasil Project (2012) \\
\hline Number of MO trees per hectare trees/ha & 2,000 & Ayerza (2012) \\
\hline
\end{tabular}

Source: Moringa Brasil Project (2012) and Ayerza (2012)

\section{Results}

Table 5 describes the initial characteristics of the synthetic effluent samples prepared for different initial turbidity values. We noticed that the turbidity results achieved are near to the 3 values established in the method due to the literature values (450, 900 and 1,350 NTU). Treated samples characteristics after the Jar Test $\backslash$ are presented in table 6 (for MO saline use) and table 7 (for direct MO use). Sample used in each assay and its initial characteristics is identified by means of table 5, and initial turbidity means values in Tables 6 and 7.

Table 5: Initial values of the dairy effluent used during the test.

\begin{tabular}{|c|c|c|c|c|c|}
\hline Sample & $\mathbf{p H}$ & $\begin{array}{c}\text { Turbidity } \\
\text { (NTU) }\end{array}$ & Electric conductivity $(\boldsymbol{\mu s} / \mathbf{c m})$ & $\mathbf{C O D}(\mathbf{m g} / \mathbf{L})$ & $\begin{array}{c}\text { Sedimentable solids } \\
(\mathbf{m L} / \mathbf{L})\end{array}$ \\
\hline $\mathbf{1}$ & 8.69 & 479 & 106.5 & $1,030.67$ & 0 \\
\hline $\mathbf{2}$ & 8.1 & 847 & 120.8 & 1,566 & 0 \\
\hline $\mathbf{3}$ & 7.59 & 1,350 & 144.8 & $2,019.33$ & 0 \\
\hline
\end{tabular}

Source: Authors.

Table 6: Physical-chemical Parameters for Dairy Effluent in MO Saline.

\begin{tabular}{|c|c|c|c|c|c|c|c|c|c|}
\hline Jar & $\begin{array}{c}\text { Coagulant } \\
\text { volume } \\
(\mathbf{m L})\end{array}$ & $\begin{array}{c}\text { Turbi } \\
\mathbf{d i t y} \\
(\mathbf{N T U})\end{array}$ & $\mathbf{p H}$ & $\begin{array}{c}\text { Final } \\
\text { turbidity } \\
(\mathbf{N T U})\end{array}$ & $\begin{array}{c}\text { Turbidity } \\
\text { removal } \\
(\boldsymbol{\%})\end{array}$ & $\begin{array}{c}\text { Conduc } \\
\text { tivity } \\
(\boldsymbol{\mu s} / \mathbf{c m})\end{array}$ & $\begin{array}{c}\text { COD } \\
(\mathbf{m g} /)\end{array}$ & $\begin{array}{c}\text { COD } \\
\text { removal } \\
(\%)\end{array}$ & $\begin{array}{c}\text { Sedimenta } \\
\text { ble solids } \\
(\mathbf{m L} / \mathbf{L})\end{array}$ \\
\hline 1 & 12.6 & 450 & 7 & 444 & $7 \%$ & 1,094 & 716.00 & $31 \%$ & 0 \\
\hline 2 & 12.6 & 847 & 7.93 & 738 & $13 \%$ & 1,212 & 886.00 & $43 \%$ & 0 \\
\hline 3 & 12.6 & 1,350 & 6.98 & 1200 & $11 \%$ & 1,120 & 966.00 & $52 \%$ & 0 \\
\hline 4 & 7.6 & 847 & 7.51 & 708 & $16 \%$ & 724.4 & 886.00 & $43 \%$ & 0 \\
\hline 5 & 4.1 & 847 & 7.16 & 652 & $23 \%$ & 467.6 & 869.33 & $44 \%$ & 0 \\
\hline
\end{tabular}

Source: Authors. 
Table 7: Physical-chemical parameters for dairy effluent in direct MO.

\begin{tabular}{|c|c|c|c|c|c|c|c|c|c|}
\hline Jar & $\begin{array}{l}\text { Coagulant } \\
\text { mass }(m L)\end{array}$ & $\begin{array}{c}\text { Turbidity } \\
\text { (NTU) }\end{array}$ & pH & $\begin{array}{c}\text { Final } \\
\text { turbidity } \\
\text { (NTU) }\end{array}$ & $\begin{array}{c}\text { Turbidity } \\
\text { removal } \\
(\%)\end{array}$ & $\begin{array}{l}\text { Conducti } \\
\text { vity } \\
(\mu \mathrm{s} / \mathrm{cm})\end{array}$ & $\begin{array}{c}\text { COD } \\
(\mathrm{mg} / \mathrm{L})\end{array}$ & $\begin{array}{c}\text { COD } \\
\text { removal } \\
(\%)\end{array}$ & $\begin{array}{l}\text { Sedimenta } \\
\text { ble solids } \\
\text { (mL/L) }\end{array}$ \\
\hline 1 & 1 & 479 & 8.17 & 233 & $51 \%$ & 132.2 & $1,079.33$ & $-5 \%$ & 9.5 \\
\hline 2 & 1 & 847 & 7.83 & 18.5 & $98 \%$ & 144.6 & $1,042.67$ & $33 \%$ & 9 \\
\hline 3 & 1 & 1,350 & 7.55 & 11.1 & $99 \%$ & 167.2 & $1,452.66$ & $28 \%$ & 9.5 \\
\hline 4 & 0.5 & 847 & 7.43 & 215 & $75 \%$ & 143.3 & $1,612.67$ & $-3 \%$ & 0.5 \\
\hline 5 & 0.75 & 847 & 7.28 & 10.6 & $99 \%$ & 146.7 & 999.33 & $36 \%$ & 2 \\
\hline 6 & 1.25 & 847 & 7.16 & 17.5 & $98 \%$ & 155.7 & $1,192.67$ & $24 \%$ & 13 \\
\hline
\end{tabular}

Source: Authors.

MO seed efficiency for dairy effluent in saline MO solution was much less efficient when compared to the MO direct use of the seed. The best turbidity removal efficiency was obtained for the $4.1 \mathrm{~mL}$ saline solution for $900 \mathrm{NTU}$, a jar with the lowest coagulant volume (lowest MO mass). This result demonstrates that there is not necessarily a linearity between the initial turbidity and the MO mass in the saline solution to obtain the maximum efficiency in the clarification of dairy effluents.

Although the MO saline test showed the best COD removal values from effluent samples in comparison to the MO direct use (flour), the maximum reduction efficiency finding was still discrete (52\%) and results in final COD values. high enough for release into a waterbody (close to $960 \mathrm{mg} / \mathrm{L}$ ).

We also observed that MO saline coagulant did not have sedimentary solids either initially or after coagulant insertion in the effluent (Tables 7 and 8), demonstrating that there was no relevant flake formation during the Jar Test. Thus, the initial conditions (mixing time, velocity gradients or $\mathrm{pH}$ range of the initial sample) for the sample did not favor the coagulation process, demanding future studies to define the optimal initial conditions that allow the correct effluent treatment, by MO saline solution.

Turbidity reduction efficiencies were much higher in MO seeds direct use. The optimal dosages found were between 1 and $1.25 \mathrm{~g} / \mathrm{L}$ for $900 \mathrm{NTU}$ and $1 \mathrm{~g} / \mathrm{L}$ for 1,350 NTU. Mostly, the turbidity reduction was greater than $95 \%$, which was lower in only two cases: low initial turbidity (where the turbidity removal was $51 \%)$ and low OM dosages $(0.5 \mathrm{~g} / \mathrm{L}$, which resulted in an efficiency of $75 \%$ ).

In both processes, $\mathrm{pH}$ was very close to 7, either MO direct use or MO saline, which makes the seed advantageous over other commercial coagulants commonly used as aluminum sulfate, which usually reduce the $\mathrm{pH}$ of the sample, avoiding expenses with the purchase of bases to correct the effluent $\mathrm{pH}$. Tables 5 to 7 show that the use of saline solution increased the electrical conductivity of the effluent raw, by the fact that the salt amount in the solution characterizes one more disadvantage.

For the MO seed direct use in the dairy effluent the results showed that the coagulant significantly removed turbidity values, reaching at least 10.6 NTU (99\%). Considering the Brazilian reality, values are below the standards established in the National Resolution (CONAMA, 2005) for discharging effluents into high quality water bodies in Brazil (up to 40 NTU).

However, the high final COD values show a limitation in the effluents discharge into waterbodies, which may demand an effluent aftertreatment system. The treated effluent could still be reused for non-human consumption, in processes internal to the dairy itself or even for cleaning, increasing the efficiency of water use in the industry and reducing the pollution of water bodies.

A disadvantage seen by the application of MO (either in aqueous or saline solution) is the longer time required for 
sedimentation to obtain considerable results (40 minutes on average) compared to commercial coagulants (Guimarães, 2005), being a viable alternative for sedimentation. Small to medium dairy industries can benefit from MO coagulant use as long as a fast effluent treatment is not required.

In Brazil (country where the tests were carried out), the use of OM becomes even more viable due to the availability of area for planting, the fact that the country has a strong agricultural culture and economy with solid emphasis on the dairy industry and has warmer temperatures, which favors MO trees growth.

\subsection{Calculation of the planting area required for wastewater treatment of a small dairy}

First, we estimated the effluent volume by equation 1, being equal to $11,220.1 \mathrm{~m}^{3} /$ year. With this result and the data in Table 4, we calculated the MO mass demand to treat this effluent, the number of trees and the required planting area, presented in Table 8.

Table 8: MO seed mass values, area and trees required for dairy effluent.

\begin{tabular}{|c|c|}
\hline Parameters & Value \\
\hline MO Mass per coagulant volume $\left(\mathrm{g} / \mathrm{L}^{\mathrm{a}}\right)$ & 0.75 \\
\hline MO Mass per year $(\mathrm{kg} / \mathrm{y})$ & 8,416 \\
\hline Area $\left(\mathrm{m}^{2}\right)$ & 1,755 \\
\hline Number of trees required & 351 \\
\hline${ }^{\mathrm{a}}$ Best result obtained in the experiments of this article \\
\hline
\end{tabular}

Source: Authors.

In addition, it is possible to estimate the mean price to acquire this property, using a mean value per square meter in Brazil in rural areas, adopted as 5,000 USD/ha (based on EMATER, 2019), thus, approximately 878 USD, a very affordable value. As many dairy products are cooperatives between different producers, the cost of MO culture can be divided between them.

That investment in such a property could be framed as an environmental compensation measure, reducing taxes of the enterprise. In addition, the leaves, roots and bark of MO tree seeds can be used as feed for dairy cows. According to Embrapa (2010), the consumption of such food can supply the animals' food shortages during the drought due to its high concentration of vitamins and nutrients, minimizing feed expenses. Besides, MO tree is easy to handle and pest resistant, avoiding expenses with pesticide and similar products. The implementation MO planting areas for use in water treatment will also promote the forested areas growth and carbon capture in the dairy vicinity, expanding the industry's sustainability index. As most dairy enterprises are small (Lima et al., 2017), MO plantations might serve several properties on a regional level, generating green jobs and collaborating for the sustainable regional development around the dairy industry.

\section{Conclusion}

The present study evaluated the use of Moringa Oleifera seed for clarification of dairy effluents. When used directly, the MO seeds showed high efficiency in the turbidity removal, showing values above $95 \%$, which indicates this coagulant as a viable alternative for the treatment of dairy effluents. Though, turbidity removal results obtained through the MO saline solution presented much lower values in comparison to the MO direct use (crushed seeds). 
A wide range of variables are linked to the flocculation process using MO seeds and can influence its efficiency, such as coagulant dosage, seed preparation type, coagulant concentration, rapid mixing time and velocity gradients, temperature, sample $\mathrm{pH}$, initial state of the sample, whether in turbidity, COD, among other parameters. All these variables somehow influence the coagulant efficiency and further studies can be performed to carefully analyze each one, consequently optimizing the coagulation process.

The MO seed use can provide an economically viable alternative in the dairy industry effluent treatment process, as well as contributing to the environment, preventing large polluting loads to contaminate the waterbodies. In addition, its use can facilitate the water reuse within the dairy industry, becoming a sustainable alternative for the effluent reuse for various purposes, minimizing the water consumption provided by the supply network.

The large-scale development of the MO coagulant production will contribute to the increase of the sustainability index in the Brazilian (or another studied country) dairy industry, a very relevant industry for the national economy. The MO plantation can also become an alternative source of income for dairy (due to the other products that can be produced) and the leaves can be used to produce dairy feed.

The authors suggest as future works more in-depth studies related to the economic and environmental viability of using OM seeds as a coagulant in wastewater treatment plants.

\section{Acknowledgments}

We thank the Coordinator of the Improvement of Higher Education Personnel (Coordenação de Aperfeiçoamento de Pessoal de Nível Superior, CAPES; in Portuguese) for the given support, evidenced by Doctor of Science scholarship award granted to Ivan Felipe Silva dos Santos. The authors would like to thank the Brazilian National Council for Scientific and Technological Development (Conselho Nacional de Desenvolvimento Científico e Tecnológico, CNPq; in Portuguese), for granting productivity in research scholarship to Prof. Regina Mambeli Barros (PQ2, Process number: 301986/2015-0). The authors thank Prof. Dr. Herlane Costa Calheiros for the concession of the Laboratory of Sanitation (LabSan) of the Institute of Natural Resources of the Federal University of Itajubá to carry out the experimental analyzes and the NGO Movimento Verde Paracatu for the seed's availability of Moringa Oleifera seeds without costs.

\section{References}

Adesina, O. O. Abdulkareem, F. Yusuff, A. S. Lala, M. \&Okewale, A. (2019). Response surface methodology approach to optimization of process parameter for coagulation process of surface water using Moringa oleífera seed. South African Journal of Chemical Engineering, $28,46-51$.

Andrade, L. H. (2011). Dairy Industry Effluent Treatment by Two Membrane Bioreactor Configurations and Nanofiltration for Reuse. Dissertation (Master in Sanitation, Environment and Water Resources). Engineering School of the Federal University of Minas Gerais (UFMG), Belo Horizonte, Brazil, 231p (In Portuguese).

Apha.(2012). Standard methods for the examination of water and wastewater. American Public Health Association, American Water Works Association, Water Environment Federation, 22th Ed. Washington.

Ayerza, R. (2012). Seed and oil yields of Moringa Oleifera variety periyakalum-1 introduced for oil production in four rcosystems of South America. Industrial Crops and Products, 36, 70-73.

Bancessi, A. Bancessi, Q. Baldé, A. Catarino, L. (2020). Present and potential uses of Moringa oleifera as a multipurpose plant in GuineaBissau, South African Journal of Botany, 129, 206-208.

Begnini, B. C. Ribeiro, H. B. (2014). Plan For Reducing Pollution Load In Dairy Industry. Health Environment, Mafra, 3, 1, 19-30, (In Portuguese).

Boulaadjoul, S. Zemmouri, H. Bendjama, Z. Drouiche, N. (2016). A Novel use of Moringa Oleifera seed powder in enhancing the primary treatment of paper mill effluent. Chemosphere, 206, 142-149.

Britt, J. H. et al. (2018). Invited review: Learning from the future - A vision for dairy farms and cows in 2067. Journal of Dairy Science, 101, $3722-3741$.

Britz, T. J.; Lamprecht, C.; Sigge, G. O. (2008). Dealing with environmental issues. In: Britz, T. J.; Robinson, R. K. (Coord). Advanced Dairy Science and Technology. Oxford: Blackwell Publishing Ltd, 35-75. 
Carnacho, F. P. Sousa, V. S. Bergamasco, R. Teixeira, M. R. (2017). The Use of Moringa Oleifera as a natural coagulant in surface water treatment. Chemical Engineering Journal. 313, 2226-2237.

CONAMA - National Council of the Environment. (2005). Resolution No. $357 \quad$ Of $\quad$ March 17 2005. <http://www.Mma.Gov.Br/Port/Conama/Res/Res05/Res35705.Pdf>. Accessed On 11 Dec. 2018 (In Portuguese).

COPASA. Sanitation Company of Minas Gerais. Methodology Developed by Copasa Available to the Sanitation Laboratory of the Federal University of Itajubá (MG). Consultation on 04/2018 (In Portuguese).

EMATER. (2019). Technical Assistance and Rural Extension Company of the State of Minas Gerais. http://www.emater.mg.gov.br/portal.do?flagweb=novosite_pagina_interna\&id=19167>. Accessed on: 07/26/19 (In Portuguese).

EMBRAPA - Brazilian Agricultural Research Corporation. (2018) Moringa Is Alternative Feeding For Cattle In Drought. 2010. <www.Embrapa.Br/SearchDe-Noticias/-/Noticia/18117821/Moringa-E-Alternativa-De-Food-O-Gado-Na-Seca>.

Fernandes, D. M. Squissato, L. A. Lima, A. F. Richter, E. M. Munoz, R. A. A. (2019). Corrosive character of Moringa oleifera Lam biodiesel exposed to carbon steel under simulated storage conditions. Renewable Energy, 139, 1263-1271.

Formentini-Schmitt, D. M. Fagundes Klen, M. R. Veit, M. T. Bergamasco, R. Ferrandin, A. T. (2014). Efficiency study of the active compound of Moringa Oleifera extracted with saline solutions in the dairy industry wastewater treatability. Engevista, 16, 2, 221-231, (In Portuguese).

Formigoni, I. (2017) Brazilian Dairy Industry: Growth And Importance. <http://www.Foodnewsoficial.Com.Br/Mercado/Industria-De-Lacteos/> .

Garde, W. K. Buchberger, S. G.; Wendell, D.; Kupferle, M. J. (2017). Application of Moringa Oleifera seed extract to treat coffee fermentation wastewater. Journal Of Hazardous Materials. 5, 102-109.

Junho, A. L. (2018). Use of oil moringa in wastewater treatment and water reuse. 75p. Final Graduation Work (Water engineering). Federal University of Itajubá.

Koche, J. C. (2011). Fundamentos de metodologia científica. Petrópolis: Vozes. http://www.brunovivas.com/wpcontent/uploads/sites/10/2018/07/K\%C3\%B6che-Jos\%C3\%A9-Carlos0D0AFundamentos-de-metodologia-cient\%C3\%ADfica-_- teoria-da0D0Aci\% C3\% AAncia-e-inicia\% C3\% A7\% C3\% A3o-\% C3\% A0-pesquisa.pdf

Lima, L. P. Perez, R. Chaves, J. B. P. (2017) The Dairy Industry In Brazil - An Exploratory Study. Bulletin Of The Food Processing Research Center, 35, 1, 113, (In Portuguese).

Liu, Y. Wang, X. Y. Wei, X. M. Gao, Z. T. Han, J. P.(2018). Values, properties and utility of different parts of Moringa oleifera: An overview. Chinese Herbal Medicines, 10, 371-378.

Lo Monaco, P. A. V. Matos, A. T. Ribeiro, I. C. A. Nascimento, F. S. Sarmento, A. P. (2010). Use Of Extract Of Moringa Seeds As Coagulant Agent In Treatment Of Water Supply And Wastewater. Ambiente \& Agua - An Interdisciplinary Journal of Applied Science, 5, 3, 222-231, (In Portuguese).

Macambira, G. M. Rabello, C. V. Navarro, M. I. V. Ludke, M. C. M. M. Silva, J. C. R. Lopes, E. C. Nascimento, G. R. Lopes, C. C. Bandeira, J. M. Silva, D. A. (2018). Chemical and nutritional characterization of moringa oleifera leaves for broilers. Brazilian Archive of Veterinary Medicine and Animal Science, 70 , 2, 570-578, (In Portuguese).

Machado, V. V. B. (2011). Ecotoxicological and chemical analysis of effluent treatment station of a dairy industry in Goiás. 2011.117 f. Dissertation (Master) - Chemistry Course, Federal University of Goiás, Goiania, (In Portuguese).

Madrona, G. S. Serpelloni, G. B. Vieira, A. M. S. Nishi, L. Cardoso, K. C. Bergamasco, R. (2010). Study of the effect of saline solution on the extraction of the Moringa Oleifera seed's active component for water treatment. Water, Air, \& Soil Pollution, 211, 1-4, 409-415.

McCain, H. R. Kaliappan, S. Drake, M. A. (2018). Invited review: Sugar reduction in dairy products. Journal of Dairy Science, 101, 8619-8640.

Moreno, M. M. B. Heredia, J. B. Gallardo, J. M. (2016). Microalgae removal with Moringa Oleifera. Toxicon, $110,68-73$.

Moringa Brazil Project - The Plant of Life. (2012). <http://Mais.Uol.Com.Br/View/F3y3fvakuqrn/Project-Moringa-A-Planta-Da-Life_De-God04020c9c3570d0a92326?Types=A\&>.

Nkurunziza, T. Nduwayezu J.B. Banadda E.N. Nhapi I. (2009). The effect of turbidity levels and moringa oleifera concentration on the effectiveness of coagulation in water treatment. Water Science and Technology, 59, 8, 1551-1558.

Paterniani, J. E. S. Mantovani, M. C. Sant'anna, M. R. (2009). Use of Moringa Oleifera seeds for surface water treatment. Brazilian Journal of Agricultural and Environmental Engineering. 13, 6.

Pereira, E.R.; Andrade, G. C. Soriani, M. Borssoi, J. A. Freitas, B. O. (2015) Use of Moringa oleifera seed as a natural coagulant without treatment of dairy effluent. In: Brazilian Congress of Agricultural Engineering, XLIV. Londrina. Annals Saint Peter: Conbea, P. 1 - 4 (In Portuguese).

Pozzobon, L. Kempka, A. P. (2015) Oil Moringa seeds in the clarification of effluent from feed ingredients industry: Comparison with conventional coagulant and study of operational conditions. Interviewer, 17, 2, 196-206, (In Portuguese).

Rangel, M. S. (2018). A natural water purifier and food supplement for northeastern Brazil. Coastal Boards. <http://www.Jardimdeflores.Com.Br/Floresefolha/A10moringa.Htm>.

Rocha, V. V. F. Santos, I. F. S. Silva, A. M. L. Sant'Anna, D. O. Junho, A. L. Barros, R. M. (2019) Clarification of high-turbidity waters: a comparison of Moringa oleifera and virgin and recovered aluminum sulfate-based coagulants. Environment, Development and Sustainability, 1, 1-12. 
Research, Society and Development, v. 10, n. 7, e21710716514, 2021

(CC BY 4.0) | ISSN 2525-3409 | DOI: http://dx.doi.org/10.33448/rsd-v10i7.16514

Saraiva, C. B. Mendonça, R. C. S. Santos, A. L. Pereira, D. A. (2009). Water consumption and effluent generation in a dairy industry. Laticinios Candido Tostes Institute, 64, 367/368, 10-18, (In Portuguese).

Silva, J. P. V. Serra, T. M. Gossman, M. Wolf, C. R. Meneghetti, M. R. Meneghetti, S. M. P. (2010). Moringa oleifera oil: Studies of characterization and biodiesel production. Biomass and Bioenergy, 34, 1527-1530.

Valverde, K. C.; Moraes, L. C. K.; Bongiovani, M. C.; Camacho, F. P. Bergamasco, R. (2013). Coagulation diagram using the moringa oleifera lam and the aluminium sulphate, aiming the removal of color and turbidity of water. Acta Scientiarum Technology, 5, 3, 485-489.

Vieira, A. M. S. Vieira, M. F. Silva, G. F. Araújo, A. A. Fagundes Klen, M. R. Veit, M. T. Bergamasco, R. (2009). Use of moringa oleifera seed as a natural adsorbent for wastewater treatment. Water, Air, And Soil Pollution, 206, 273-281.

Villa, R. D.; Silva, M. R. A. and Nogueira, R. F. P. (2007). Potential for photo-fenton / solar application as effluent pretreatment of the dairy industry. Quím. Nova, 30, 8, (In Portuguese).

Villaseñor-Basulto, D. L. Sánchez, P. D. A. Olvera, J. D. R. Bandala, E. R. (2018). Wastewater treatment using Moringa oleifera Lam seeds: A review. Journal of Water Process Engineering 23, 151-164. 